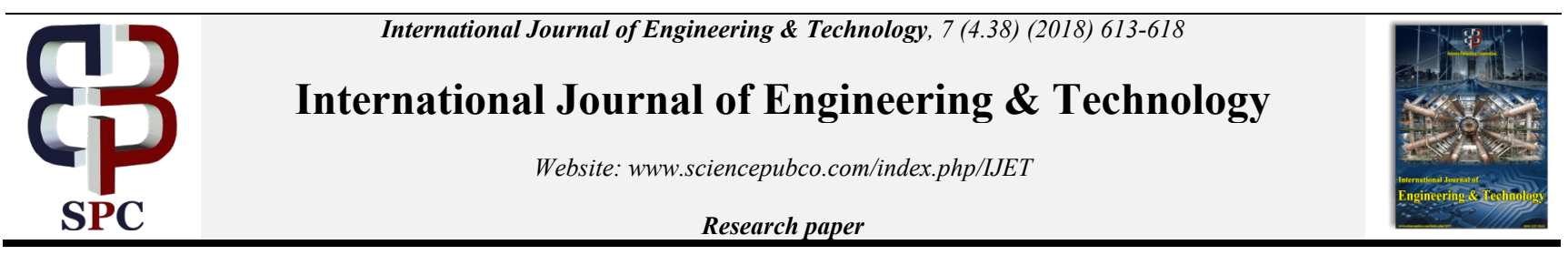

\title{
Theoretical Justification and Calculation of the Integral Indicator Related to Innovative Activity of an Organization
}

\author{
Ekaterina Vasilieva $^{1 *}$, Evgeniy Vasiliev ${ }^{1}$, Elena Danilova ${ }^{1}$ \\ ${ }^{1}$ Volgograd State University, Universitetsky Av., 100, Volgograd, 400062, Russian Federation \\ *Corresponding author E-mail: 176171@mail.ru
}

\begin{abstract}
The current economic and political situation poses challenges for the further development of the Russian economy. Problems of the discrepancy between the existing economic, administrative, regulatory framework and the tasks set were identified during the implementation of the National Technological Initiative 2035. Problem of compatibility of social organization and ability of social systems to change is becoming urgent. To efficiently overcome the identified difficulties, it is necessary to develop the existing theories of organizational development (hereinafter - OD), the organization's innovative activity being an important component of many of them. Formation of empirical data is required for the formation of strategic plans within the framework of OD theories. The adapted author's system of innovative indicators was used to solve this problem in the study.

Innovative activity of any organization can be viewed as a sequential cyclic passage of stages that generally describe the life cycle of any innovative product, from the moment of inception to achieving specific economic results while implementing the final innovative solution. A promising rating method is proposed as part of the adapted system to determine the share of innovatively active personnel in enterprises. This method can be successfully applied in an enterprise of any size and any branch of the economy. It is suggested to use wellestablished economic methods (dynamic approach, efficiency approach, dynamic efficiency approach), which allows to control and subsequently correct any aspects of the enterprise activity related to innovation at various stages of implementation of innovative ideas (projects).

As a result, using an integrated assessment of the innovative activity of the enterprise as a source of empirical data to determine the dynamics of development of organizations in the population under consideration, as well as the main provisions of the population selection model of OD allows to identify organizations that produce "perfect change patterns" and model innovative and OD processes applied to a specific organization, given the forecasting of the results of the changes implemented in the market sector.
\end{abstract}

Keywords: organizational development, efficiency of the organization, mechanisms and logic of changes, perfect samples, innovative activity, measurement of innovative activity, indicators of innovative activity, rating system of evaluation, dynamic approach, efficiency approach, dynamic efficiency approach, management of innovation-driven growth, system of innovative indicators.

\section{Introduction}

The current development of Russia in some point fits into the generally accepted laws at this stage of development of economic mind. However, the moderate pace of development does not correspond to the strategic interests of the Russian Federation in the current economic and political situation. After analyzing the level of technological reserves in the relevant and promising fields, the Government of the Russian Federation decided to develop and implement the National Technological Initiative 2035 [1] in 2015. This decision allowed to determine the implementation mechanism and plans [2] in the first half of 2016. Practical implementation raised the problem of discrepancy between the existing administrative and regulatory framework and the tasks set. As such, studies aimed at creating the theories of OD in relation to the current state of Russia become relevant.

This necessitates justification of the research position in relation to the existing theories of organizational development (OD), organization's innovative activity being an important component of many of them. The very OD is viewed as a type of change "where one social object (targeted rigidly structured social community) combines such features as obvious ordering in processes that oc- cur in the organization and capability of directed change, which manifests itself in voluntarism that involves choosing a strategy" [3]. This assumption leads to the junction of two fields of research: economic and sociological ones.

Russian researchers started using the term "organizational development" relatively recently (approximately in the mid-1980s). At the same time, it was often used in the ideologized version - as opposed to the concepts of "stagnation" or "functioning processes of the organization". However, research of the OD processes overseas has a long history, and views on the OD are more multilateral and diverse. Several terms are often used there to denote what is called by the single term OD in Russian: "organizational development", "organizational growth", "organizational design", "organizational construction", etc. [4]. There are also serious disagreements in understanding of its concept. Highlighting the three most typical and well-established definitions will illustrate this.

According to the first definition, it is a natural process of qualitative changes in the organization, derived from its age [5]. According to the second definition, the OD is a process associated with changes in the organization that contribute to the growth of its headcount and its size and are determined by innovations, and most directly relates to innovative changes $[6,7]$. In the third case, it is a complex strategy aimed at changing the structure of social relations and people's views with the purpose of ensuring its adap- 
tation to the requirements of technology and the market [8]. This results in three different and poorly comparable definitions of one phenomenon. The very definition of a process with the same name is given on so many different grounds that the question naturally arises: do different researchers discuss the same phenomenon? However, a deeper comparison of these definitions allows to see general aspects despite their obvious difference. Firstly, they describe only organizational changes. Secondly, we are talking about a certain type of organizational changes, described by a set of recognizable, albeit heterogeneous, factors. Thirdly, the emphasis is on the qualitative aspects of development. Obviously, changes of this type are described by being reflected in the organizational structure. Fourthly, there is a notion of directed changes in all definitions, in an explicit or implicit form, - i.e. changes with a certain predetermined vector, focused on achieving a certain ultimate result. Finally, it is almost always about positive results of changes.

As such, following the classical concepts (schools of social systems, structural situational and neoinstitutional approaches, theory of resource dependence, theory of life cycles of an organization, organizational ecology, etc.)actually presented in the modern organizational theory, the authors believe that it is worth considering the organization's ability to survive in a dynamic external environment as an integral criterion for the positivity of changes in the organization, which to some extent requires implementation of innovative projects.

Innovative activity of the organization underlies most rationalistic models [9-16]. Following the logic of the representatives of rationalistic models, strategic and innovative activities are a process of structural changes controlled and managed by the managers of the organization with a predictable and expected result.

However, over the past decades, lots of data have been accumulated that record discrepancy between the real behavior of organizations and the basics of popular rational systemic OD models. The results of empirical studies of the foreign [17] and domestic authors [18] demonstrated discrepancy between the active structural changes occurring in organizations and the basic postulates of rationalistic OD models.

Similarity was found in the only fact that changes occurring in the organizational environment (macro environment) have always triggered changes in organizations. The rest of the conclusions drawn on the basis of studies of the above academicians radically changed the attitude toward the existing OD models.

1. There was no one-way and step-by-step process of social and institutional changes in the development of individual organizations. However, the logic of step-by-step structural changes inherent in rational systemic OD models was clearly seen in the population of the reviewed organizations. This circumstance forced the researchers operate not so much with individual organizations as with the population of organizations, calling it an "organizational population" [17].

2. Most of the long-established organizations in the population that appeared during the period of surplus in resources and low population density normally remained small in number and retained the structure typical for undeveloped organizations (as opposed to systemic canons), while organizations that emerged later, in the period of narrowing resource niches, were initially formed as larger, diversified and structured [3]. This observation allowed to clearly divide the organizations of the population into "closed" and "open" ones.

3. The processes of change occurred unevenly, with significant "interruptions of gradualness" [17]. These delays were due to the organizations' unwillingness to make radical changes in the external environment, which correlated well with the current situation in the implementation of roadmaps for the implementation of the NTI 2035 program.

4. The growth in the innovative and strategic activities of each organization was due to a change in the OD logic in managers of this organization, provoked by the challenge of the environment.
5. Actual changes in the organization following the results of innovative and strategic activity in most cases turned out to be very remote from the goals set in the development programs. As a result, innovative projects very rarely found application of the organization's activities in their originally planned form.

6. Nevertheless, projects that proved their efficiency (for the most part being significantly transformed in the implementation process) were distributed among all the organizations survived during changes in a short time. As such, using the "fund of successful changes" ("perfect patterns of change"), i.e. innovations, described the logic of transformation of organizations as a group adaptation, rather than an individual adaptation to the changing environment [19].

The newly formed OD model is known as the "population selection model of OD". This model allows managers to solve a range of practical problems: identify "perfect patterns of change" obtained by the logic of natural selection, simulate the processes of innovation-driven growth as applied to a particular organization, taking into account the forecast of the results of the implemented changes. Within the framework of this model, innovation activity is only a reaction to the extreme processes occurring in the external environment of a specific population of organizations.

The use of the population selection model of OD is possible due to the toolkit for assessing the innovative activity of the organization population (the population is understood as an aggregate of organizations operating in a certain market). The model allows to describe strategies for this market development and to identify organizations that are sources of the "perfect patterns of change" replicated by the rest of the population, and to identify organizations operating in a "closed system" and therefore doomed to extinction, displacement from this market.

\section{Methods}

Whole scientific communities are engaged in the development of toolkits and innovative indices in the West, for whom the index building systems are also not an end in itself but a source of empirical data for the formulation of a research position [20-23].

Certain complexity arises at the stage of choosing toolkits for analyzing the innovative activity of organizations. Therefore, it becomes important to develop a toolkit that allows rapid assessment of organizational and innovation processes on the scale of the institutional unit - an individual organization [4, 24]. Performance evaluation of the most representative organizations of the industry will allow to subsequently draw conclusions about the whole sector of the market.

There are many approaches to evaluating activities in a particular field. The choice is usually made between quantitative and qualitative methods depending on the required volume, accuracy and speed of the evaluation. However, in some cases, it is advisable to resort to expert opinion, the advantage of which is revealed in saving all costs. Such expert methods do not allow to solve the task in full but allow to single out the main problem or a factor that requires more detailed consideration using quantitative and qualitative methods.

Innovative activity is a complex, constantly changing manifestation of the OD, and the development of an objective system of indicators requires that this system includes categories that evaluate the work of the employees, the system for managing the emerging ideas, and, of course, indices of economic performance of the organization $[4,25]$.

Most of the required indicators can be formed using quantitative assessment methods based on two approaches: functional and resultant [26]. The smaller part may require the use of a third factor-based approach, and the staff performance can be evaluated using a rating assessment.

The organizational conditions for the development of innovative activity of the organization's personnel primarily assume an assessment of the existing level of innovation. It is advisable to ap- 
ply a rating assessment to obtain this indicator. The use of the rating assumes the analysis of not just one object but rather of a certain set of objects, within which they are compared. The integral indicator provides additional information that helps evaluate the performance results of the object as objectively as possible based on identifying qualitative and quantitative deviations from the reference base. As a result, researchers get a set of ranked ratings in the end that allow not just to draw a conclusion about the degree of innovative activity of a particular employee, but also about the conditions for the formation of this activity [27].

A peculiarity of using the functional approach to evaluate the innovative activity of the organization is that it uses indicators of the intensity of implementation of certain types or components of activities by the organization.

This approach has both advantages and disadvantages. Advantages of the functional approach include simplicity, universality and minimum of the required source data. Disadvantages are that this approach does not allow taking the final results of the organization's innovation activity into account and, as a result, does not allow to evaluate its efficiency and impact on the OD process. Another disadvantage is that the implementation of this approach does not allow to separate the routine, everyday processes for production from really innovative ones.

In turn, the resultant approach uses indicators that describe precisely the results of the organization's activities, which in the context of our study are the results of innovative activity. Within the framework of the resultant approach, there are three more particular methods of division: dynamic, efficiency and dynamic efficiency [26]:

- the dynamic method assumes an estimation of innovative activity of the organization using indicators describing the intensity of innovative developments being implemented by the organization;

- the efficiency method is based on the evaluation of the organization's innovative activity using indicators expressing the degree to which this organization achieves ultimate goals of its operation, which its innovative activity is primarily focused on;

- the dynamic efficiency method is the most developed approach in the resultant group, since it enables to evaluate the innovative activity of the organization using complex indicators that integrate both the evaluation of the dynamics of innovation developments implemented by the organization and the efficiency of such developments. As such, within the framework of this approach, the main shortcomings of the two previous approaches are eliminated, which are: for the dynamic approach - the lack of consideration of economic results of innovative activity; for the efficiency approach - the lack of consideration of speed parameters for the implementation of innovative developments.

The main disadvantage of the resultant approach is that it only allows to record the activity level of the organization based on its results. However, this approach does not allow to identify the prerequisites that shape and define the dynamics of the organization's activities and define the OD direction.

The factor resultant approach generally tries to use the merits of functional and resultant approaches and allows to combine both the factors and the results of the organization's activities. Within the framework of this approach, both the indicators of the resultant approach and a range of additional specific indicators are used to evaluate the innovative activity of the organization, in particular: indicators of duration of individual stages of innovative developments; indicators of the organization's product modernization dynamics; volume of new technologies transferred by the organization within the technology transfer systems; volumes of new products exported by the organization; number of new technologies and products introduced over the period, etc.

All the obtained indicators should be linked to a complex system described by a final integral indicator that will reflect the level of innovative activity of a particular institutional unit [28]. The author's method for calculating the integral indicator of innovative activity of small and medium-sized businesses was chosen to form the empirical base of the research [29]. The presented system for evaluating the innovative activity of organizations allows to conduct a detailed assessment at each stage of innovation implementation and to identify cause-and-effect relationships that determine the efficiency of innovative activities of organizations, which combined with a population selection OD model allows to describe the development strategy for this market sector and define organizations that are sources of the "perfect patterns of change".

\section{Results}

Organizations engaged in the sale and maintenance of computer equipment in Volgograd and the Volgograd region were the object of the study. At the moment, 5 major players occupy a dominant position in this market. Due to confidentiality of the provision of financial, statistical and management information, the names of organizations are not disclosed.

The organizations' activities were analyzed for the period from 2015 to 2017. To carry out a detailed evaluation of the current changes in this population, intermediate indices and a final integral indicator of innovative activity have been calculated following the results of the annual activity, which will provide a reasoned evaluation of processes taking place in this trading sector in Volgograd and the Volgograd region in future and identify donor organizations that develop "perfect samples of changes" which will later be replicated by the rest of the population.

The integral indicator of the organization's innovative activity consists of four intermediate indices in the method used: the index of preparedness for innovation, the index of introduction of innovations, the index of feasibility of innovations, the index of efficiency of innovative ideas (projects) (Table 1). Each of the indices exerts certain influence and has its own weight coefficient determined by expertise.

Table 1: Font Specifications for A4 Papers

\begin{tabular}{|c|c|c|}
\hline Indicator name & $\begin{array}{c}\text { Indicator } \\
\text { designation }\end{array}$ & Standard \\
\hline Index of preparedness for innovation & $|P|$ & $0.5-1.0$ \\
\hline $\begin{array}{l}\text { Share of employees generating most of the } \\
\text { ideas, concepts, in the total number of em- } \\
\text { ployees }\end{array}$ & $K_{I S}$ & \\
\hline $\begin{array}{c}\text { Share of innovative projects (concepts) in the } \\
\text { total number of generated and formulated } \\
\text { ideas }\end{array}$ & $I P$ & \\
\hline $\begin{array}{l}\text { Preparedness of the organization's fixed } \\
\text { assets for innovation }\end{array}$ & $\mathrm{Fa}$ & \\
\hline $\begin{array}{l}\text { Preparedness of the organization's personnel } \\
\text { for innovation }\end{array}$ & $P_{I S}$ & \\
\hline $\begin{array}{l}\text { Preparedness of the organization for invest- } \\
\text { ing in innovative projects }\end{array}$ & $P_{I I}$ & \\
\hline Index of introduction of innovation & III & $>0.1$ \\
\hline $\begin{array}{c}\text { Share of innovative ideas (projects) that } \\
\text { passed the selection for introduction in the } \\
\text { total number of ideas (projects) }\end{array}$ & $M F$ & \\
\hline $\begin{array}{l}\text { Share of employees involved in the imple- } \\
\text { mentation of innovative ideas (projects) in } \\
\text { the total number of employees of the organi- } \\
\text { zation }\end{array}$ & & \\
\hline $\begin{array}{l}\text { Coefficient of using new equipment for in- } \\
\text { troduction of innovative ideas (projects) }\end{array}$ & $E F a$ & \\
\hline $\begin{array}{c}\text { Share of costs for introduction of innovative } \\
\text { projects, in the total number of costs of the } \\
\text { organization }\end{array}$ & $K_{I F C}$ & \\
\hline Index of feasibility of innovation & $I_{F I}$ & 0.7-1.0 \\
\hline $\begin{array}{l}\text { Share of implemented innovative ideas (pro- } \\
\text { jects) in the number of ideas (projects) that } \\
\text { have passed the selection for introduction }\end{array}$ & $K_{C I P}$ & \\
\hline $\begin{array}{l}\text { Share of time spent on the implementation of } \\
\text { innovative projects in the planned time }\end{array}$ & $K_{E}$ & \\
\hline
\end{tabular}




\begin{tabular}{|c|c|c|}
\hline $\begin{array}{l}\text { Share of costs for the implementation of } \\
\text { innovative ideas (projects) in the planned } \\
\text { costs }\end{array}$ & $K_{E P F C}$ & \\
\hline $\begin{array}{c}\text { Share of new employees of the organization } \\
\text { involved in the implementation of the inno- } \\
\text { vative project in the initial number of em- } \\
\text { ployees }\end{array}$ & $K_{E O S}$ & \\
\hline Index of efficiency of innovation & $I_{E I}$ & $>1.0$ \\
\hline $\begin{array}{c}\text { Profit growth rate in the period of efficiency } \\
\text { of innovative projects }\end{array}$ & $K_{I P}$ & \\
\hline $\begin{array}{l}\text { Share of investments in new innovative pro- } \\
\text { jects }\end{array}$ & $K_{I G}$ & \\
\hline Coefficient of expansion of the organization & $K_{E X C}$ & \\
\hline $\begin{array}{l}\text { Coefficient of growth in the number of inno- } \\
\text { vative employees in the organization }\end{array}$ & $K_{E X S}$ & \\
\hline $\begin{array}{c}\text { Integral indicator of innovative activity of } \\
\text { the organization }\end{array}$ & $I_{I A}$ & $>0.6$ \\
\hline
\end{tabular}

The main difficulty in evaluating the innovative activity of the organization is that the innovation activity is described by heterogeneity. Many actions are required from the inception of an idea to the implementation of a specific project, and their results can be affected by both internal and external factors.

Therefore, the evaluation must be carried out in certain stages, which fully describe the process of innovative activity [30]. Management of innovation activity is divided into four stages within the framework of the presented system of indicators.

Table 2 presents values of indices and integral indicator of the organization's innovative activity for the period under study.

Table 2: Dynamics of values of indices and the integral indicator of innovative activity of the population of organizations under study for the period 2015-2017

\begin{tabular}{|c|c|c|c|}
\hline Organizations & 2015 & 2016 & 2017 \\
\hline \multicolumn{4}{|c|}{ Index of preparedness for innovation } \\
\hline Organization A & 0.51 & 0.53 & 0.56 \\
\hline Organization B & 0.75 & 0.85 & 0.67 \\
\hline Organization $\mathrm{C}$ & 0.29 & 0.28 & 0.26 \\
\hline Organization D & 0.46 & 0.39 & 0.38 \\
\hline Organization E & 0.46 & 0.58 & 0.61 \\
\hline \multicolumn{4}{|c|}{ Index of introduction of innovation } \\
\hline Organization A & 0.23 & 0.29 & 0.28 \\
\hline Organization B & 0.40 & 0.32 & 0.34 \\
\hline Organization $\mathrm{C}$ & 0.17 & 0.16 & 0.12 \\
\hline Organization D & 0.16 & 0.12 & 0.12 \\
\hline Organization E & 0.12 & 0.12 & 0.12 \\
\hline \multicolumn{4}{|c|}{ Index of feasibility of innovation } \\
\hline Organization A & 0.65 & 0.73 & 0.71 \\
\hline Organization B & 0.77 & 0.80 & 0.89 \\
\hline Organization $\mathrm{C}$ & 0.55 & 0.65 & 0.58 \\
\hline Organization D & 0.69 & 0.93 & 0.57 \\
\hline Organization E & 0.89 & 0.89 & 0.82 \\
\hline \multicolumn{4}{|c|}{ Index of efficiency of innovation } \\
\hline Organization A & 1.57 & 1.08 & 1.08 \\
\hline Organization B & 1.02 & 1.06 & 2.07 \\
\hline Organization C & 1.41 & 1.39 & 0.89 \\
\hline Organization D & 1.41 & 1.78 & 0.92 \\
\hline Organization E & 0.95 & 1.31 & 1.73 \\
\hline \multicolumn{4}{|c|}{$\begin{array}{l}\text { INTEGRAL INDICATOR OF INNOVATIVE ACTIVITY OF THE OR- } \\
\text { GANIZATION }\end{array}$} \\
\hline Organization A & 0.81 & 0.70 & 0.70 \\
\hline Organization B & 0.76 & 0.79 & 1.08 \\
\hline Organization $\mathrm{C}$ & 0.67 & 0.68 & 0.50 \\
\hline Organization D & 0.74 & 0.89 & 0.54 \\
\hline Organization E & 0.65 & 0.78 & 0.90 \\
\hline
\end{tabular}

To get a complete picture of changes in the population of the reviewed organizations during the period under study, the dynamics of each of the indicators should be considered in detail.

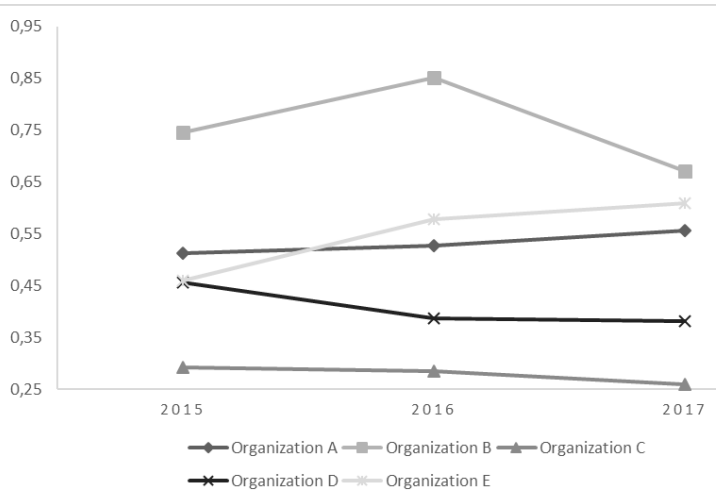

Fig. 1: Dynamics of the index of preparedness for innovations of organizations under analysis, 2015-2017

Fig. 1 demonstrates the dynamics of the index of preparedness for innovation of organizations under analysis for the period 20152017 as a chart. At the beginning of the period under study, only two organizations ("A", "B") corresponded to the standard, but organization "E" joined them by the end of 2017, having improved its position by $33 \%$. Organization "B" still remains the leader of preparedness for innovation, despite the decline by $10 \%$. If the intermediate values of this index are considered, then the stable position of organization "A" is also worth noting. Organizations " $\mathrm{C}$ " and " $\mathrm{D}$ " demonstrate a constant decline in the preparedness to implement innovative projects, which describes them as "partially closed type" systems [31]. Organizations of this type consider their internal environment as the main source of uncertainty (which should be reduced or compensated): personnel, organizational culture, technology, implemented goals and strategies. Consequently, they are not able to respond adequately to changes occurring in the environment. This leads to extinction in most cases.

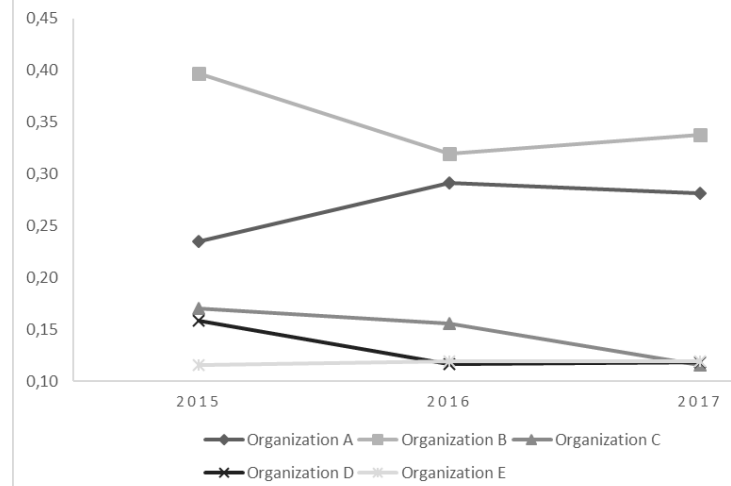

Fig. 2: Dynamics of the index of introduction of innovations in organizations under analysis, 2015-2017

Dynamics of the index of introduction of innovation also emphasizes organizations "A", "B" and "E". Organizations "A" and "E" were the only ones out of the entire population to demonstrate growth over the entire period under analysis. Meanwhile, the indicator of organization "B", though having demonstrated a $15 \%$ decrease, is still significantly higher than its partners in the population. It must be noted that despite the ambiguous trends in all the members of the population, their indicators throughout the analyzed period are higher than the standard ones. This suggests that each of the organizations not just spends sufficient funds for the implementation of innovative projects but also maintains the necessary balance in this process. Nevertheless, a negative trend for a number of organizations, revealed in the analysis of the previous indicator, is also seen in the dynamics of this index. Organizations "C" and "D" demonstrate a consistent decrease in the index of introduction by $32 \%$ and $25 \%$, respectively (Fig. 2 ). 


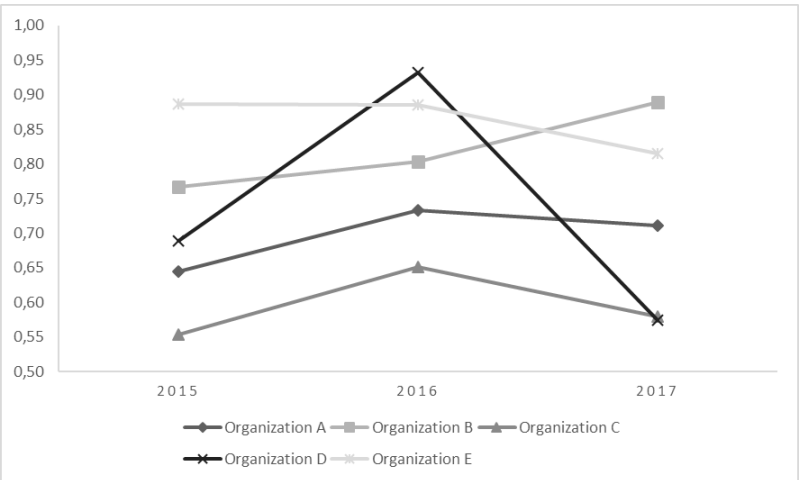

Fig.3: Dynamics of the index of feasibility of innovations in organizations under analysis, 2015-2017

This index demonstrates the quality of implementation of innovative projects. Organizations "A", "B" and "E" demonstrate their confident position once again. The growth of organization "B" to the level of $0.89(+16 \%)$, which is close to the theoretical maximum, is worth noting. The index of feasibility of innovations in organization "E" equal to 0.82 in the end of 2017 must also be mentioned. Besides, although this is the result of a gradual decline, it must be taken into account that this organization demonstrates the highest average level of this index $(0.86)$ in the entire population under study (Fig.3).

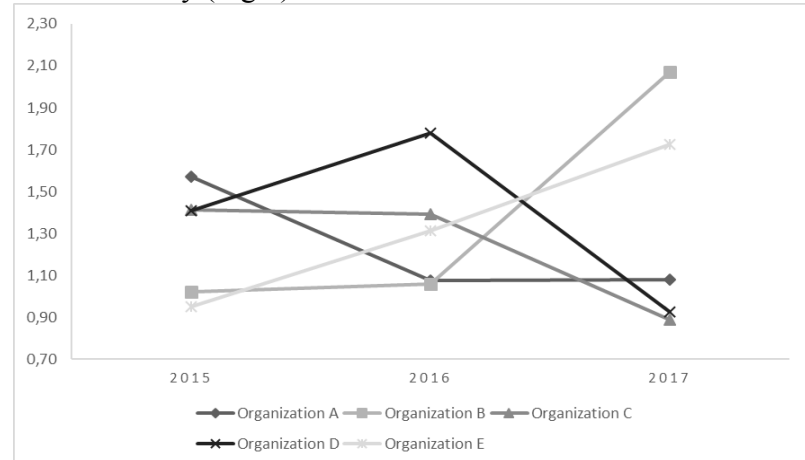

Fig.4: Dynamics of the index of efficiency of innovative projects in organizations under analysis, 2015-2017

Only three organizations ("A", "B" and "E") were above the standard value by the end of the period under study. While organization "A" showed a decline by $31 \%$ and was on the edge with the index value of 1.08 , organizations "B" and "E" were leading with an increase in the index by $102 \%$ and $81 \%$, respectively, and the index values significantly exceeded standard requirements. Organizations " $\mathrm{C}$ " and " $\mathrm{D}$ " regularly demonstrated the most noticeable negative dynamics of the index and were below the standard value by the end of the period under analysis. It is worth noting that this decline took place only in 2017 (Fig.4).

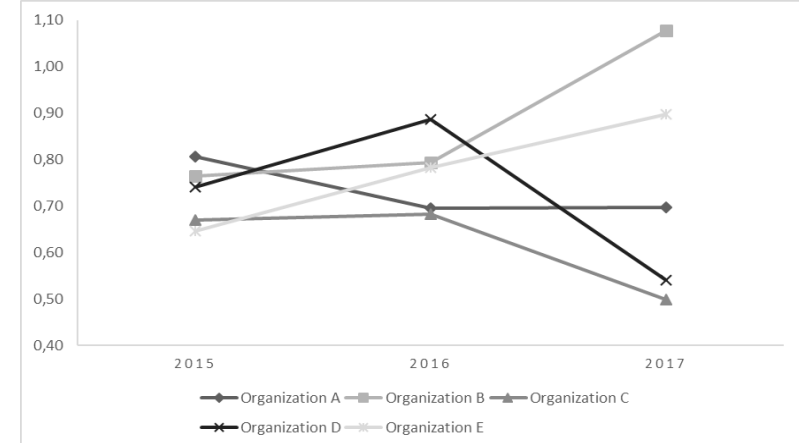

Fig.5: Dynamics of the integral indicator of innovative activity of organizations under analysis, 2015-2017

Analysis of the dynamics of the integral indicator of innovative activity of the analyzed organizations allows to draw a general conclusion about organizations and the population as a whole.
Two organizations ("B" and "E") have positive indices compared with the population throughout the analysis. Obviously, these two organizations are sources of the formation of a "fund of changes" for the entire population. Organization "A" is not so confidently implementing its strategy of innovation-driven growth - nevertheless, despite the decrease in the integral indicator by $14 \%$ by the end of 2017, it has the necessary resources to change the situation for the better (Fig.5). This is suggested by consistent work, the results of which can be seen in the systematic strengthening of the index of preparedness for innovation.

As a result, these three organizations ("A", "B" and "E") can be classified as "selectively open systems" [31], which allows them to be ready for efficient interaction with the environment in the context of instability. Position of these organizations is clearly demonstrated on the tabular diagram of the final values of the integral indicator and the components of the innovative activity indices of the organizations under analysis (Fig.6).

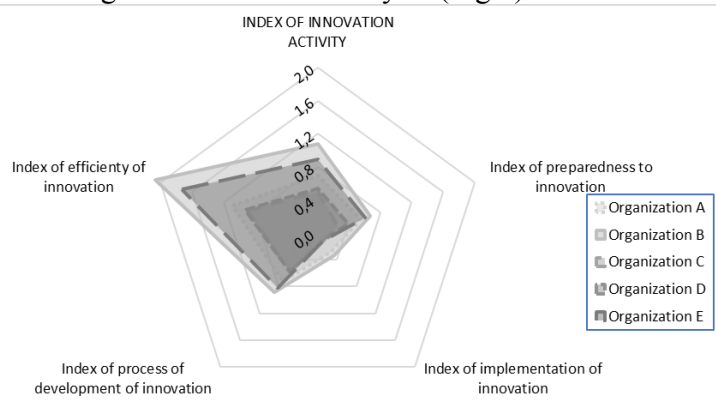

Fig.6: Values of the integral indicator and innovative activity indices in organizations under analysis, 2017

On the contrary, organizations " $\mathrm{C}$ " and " $\mathrm{D}$ " demonstrate immunity to external changes and the results of the analysis indicate either their extinction or withdrawal from this market sector.

\section{Discussion}

This study supplied the necessary volume of empirical data to formulate a forecast for the further development of the market sector (sales and maintenance of computer equipment in Volgograd and the Volgograd region). As expected, there was no uniform unidirectional process of institutional changes among the separately examined organizations. Actions of some organizations were either fairly passive or unnecessarily chaotic.

The obtained data allow to assert that the innovative activity among the organizations under study was activated only as a response to the threats of the environment and was described by a lack of consistency and uniformity. This led to "interruptions in gradualness" [17], which did not allow to gain the necessary positive "cumulative" effect from the introduced changes. However, as the OD logic of managers in organizations that benefited from changes changed, the efficiency of strategic planning increased (among organizations using "perfect patterns of change"). In turn, this led to a cascading growth of innovative changes.

Although most of the introduced innovations did not lead directly to the goals originally underlying the development projects, the results often found application in the activities of organizations. At the same time, projects that had proved their efficiency were replicated by the most active organizations in the population under study with sufficient success (the process of forming the "perfect patterns of change"). At the same time, the process of radical changes in this market sector leads to a decrease in the "width of the ecological niche", which in turn increases the "mortality" or the prospects for "mortality" of the existing organizations in this niche that do not have a sufficient array of accumulated organizational changes that would allow them adequately transform their activities. 


\section{Conclusion}

Summarizing the results of the study, the following conclusions can be drawn. Using an adapted integrated evaluation of the innovative activity of an enterprise as a source of empirical data to determine the dynamics of development of the organizations in the population under study, along with the main provisions of the population selection model, it becomes possible to identify organizations that produce "perfect patterns of change" and model innovative and OD processes applied to a specific organization, taking into account the forecasting of the results of the implemented changes.

The process of integrated evaluation of innovative activity of each organization in the population under study supplies data describing the innovative activity of the enterprise over time and at each stage of development and implementation of innovations. The data obtained as a result of the study illustrate the sources of successful innovation in this population of organizations and also allow to determine the current level of implementation of organizational changes in a particular period of time with a sufficient accuracy. The set of empirical data obtained as a result of the activity analysis of the population of organizations allows to draw conclusions about the sector of the economy represented by the organizations under study, within the population selection model of OD.

\section{Acknowledgement}

The article is a part of the scientific project No. 17-13-34010 "Resource Potential of Nonprofit Organizations in the Field of Social Entrepreneurship" funded by the RFBR (Russian Foundation for Basic Research) and the Administration of the Volgograd region. Contacts with project coordinators: Ekaterina Vasilieva (vasilevaen@volsu.ru), Evgeniy Vasiliev (vasileves@volsu.ru), Elena Danilova (danilovaelena@volsu.ru).

\section{References}

[1] Decisions following the results of the meeting of the Presidium of the Presidential Council for Modernization of the Economy and Innovation-Driven Growth of Russia. The Russian Government. http://government.ru/orders/selection/401/18547/.

[2] Resolution No 317 (April 18, 2016). On the implementation of the National Technological Initiative. The Russian Government. http://government.ru/docs/22721/.

[3] Shcherbina VV (2015), Populyatsionno-selektsionnaya model organizatsionnogo razvitiya: soderzhaniye, sfera i perspektivy primeneniya [Population selection model of organizational development: content, scope and prospects of application], Sociological Research, 8(376), 100-108.

[4] Glassman AM \& Cummings T (1991), Cases in Organizational Growth and Development. Homewood-Boston.

[5] Starbuck WH (1965), Organizational growth and development. Chicago, Handbook of Organizations, Rand McNally, 451-533.

[6] Child J \& Kieser A (1981), Development of Organizations over Time: Handbook of Organizational Design, Oxford University press, $1,28-64$

[7] Gotsch M \& Hipp C, Innovation measurement for knowledge intensive business services: Suitability of trademarks as additional indicator of innovation. ResearchGate. https://www.researchgate.net/publication/267785897 Innovation Measure-

ment for Knowledge Intensive Business Services Suitability of Trademarks as Additional Indicator of Innovation.

[8] Bennis W (1969), Organization Development Reading. Addisson Wesley.

[9] Ansoff I (1989), Strategicheskoye upravleniye [Strategic management]. Moscow, Economics.

[10] Mintzberg H, Quinn J, Ghoshal S (2001), The Strategy Process. Saint Petersburg, Piter.

[11] Pugh DS \& Hickson DJ (1997), Writers on Organizations: Reading book. Moscow.
[12] Dudchenko VS (1989), Innovatsionnyye igry [Innovative games]. Tallinn, Valgus.

[13] Lapin NI (2008), Teoriya i praktika innovatiki [Theory and practice of innovation theory]. Moscow, Logos.

[14] Prigozhin AI (1989), Novovvedeniya. Stimuly i prepyatstviya [Innovations. Incentives and obstacles]. Moscow, Politizdat.

[15] Prigozhin AI (2003), Metody razvitiya organizacij. Moscow, MCFEHR.

[16] Meshkov AA (1996), Osnovnyye napravleniya issledovaniya innovatsiy $\mathrm{V}$ amerikanskoy sotsiologii [Main areas of innovation research in American sociology]. Sociological Research, 5, 117-128.

[17] Hannon MT \& Freeman J (2010), Strukturnaya inertsiya i organizatsionnyye izmeneniya. Upravleniye izmeneniyami [Structural inertia and organizational change. Managing changes]. Saint Petersburg, HSM, 2-38.

[18] Shcherbina VV \& Ermolaev VN (2005), Organizatsionnoye razvitiye stomatologicheskikh klinik Moskvy [Organizational development of dental clinics in Moscow]. Sociology, 1, 124-145.

[19] Stinchcombe A (1965), Social structure and organizations. Chicago, Handbook of Organizations, 142-193.

[20] Andries P \& Czarnitzki D (2014), Small firm innovation performance and employee involvement. Small Business Economics, 43(1), 21-38.

[21] Crossing the Next Regional Frontier: Information and Analytics Linking Regional Competitiveness to Investment in a KnowledgeBased Economy. StatsAmerica. http://www.statsamerica.org/innovation/reports/crossing_regional_f rontier full report.pdf.

[22] NYCEDC Innovation Index 2011. NYCEDC. http://www.nycedc.com/sites/default/files/filemanager/Resources/E conomic Data/InnovationIndexReport.pdf.

[23] Productivity and Growth in UK Industries. Imperial College London Business School. https://spiral.imperial.ac.uk/bitstream/10044/1/9027/1/Haskel\%202 011-06.pdf.

[24] Boyer T \& Blazy R (2014), Born to be alive? The survival of innovative and non-innovative French micro-start-ups. Small Business Economics, 42(4), 669-683.

[25] Vasilieva EN \& Gulyaikhin VN (2014), Ekonomicheskaya sotsializatsiya uchashcheysya molodezhi: opyt regionalnogo issledovaniya [Economic socialization of students: practice of regional research]. Sociological Research, 8(364), 115-119.

[26] Vlasova AE (2013), Osnovnyye pokazateli, ispolzuyemyye dlya otsenki innovatsionnoy aktivnosti roznichnykh torgovykh predpriyatiy [Main indicators used to assess the innovation activity of retail trade enterprises]. Volga Trade and Economic Journal, 6(34), 73-84.

[27] Vasilieva E, Danilova E \& Tokareva S (2017), Migration attractiveness of the social and economic spaces: Volgograd case study. Theoretical and Empirical Researches in Urban Management, 12(1), 5-20.

[28] Vasiliev ES \& Lisovskaya NV (2014), Analiz dinamiki indeksa innovatsionnogo potentsiala sovremennoy Rossii [Analysis of dynamics of the index of innovative potential of modern Russia]. Bulletin of the Volgograd State University, 3: Economy, Ecology, 1, 58-65.

[29] Vasiliev ES \& Vasilieva EN (2015), Razrabotka sistemy rascheta integralnogo indeksa innovatsionnoy aktivnosti predpriyatiy malogo i srednego biznesa [Development of the system for calculating the integral indicator of innovative activity of small and medium-sized businesses]. Internet journal Science Studies, 7, 6(31), 17.

[30] Zakharova MI (2014), Razrabotka sistemy pokazateley dlya otsenki innovatsionnoy aktivnosti [Development of a system of indicators for evaluating innovative activity]. Bulletin of the IrSTU, 11(94), 280-284.

[31] Kast FE \& Rosenzweig JL (1972), General System Theory. Application for Organization and Management. Academy of Management Journal, 447-464. 